\title{
The duty of good faith: How does it apply on the termination of a pension scheme? \\ Received: 21st February, 2003
}

\section{Tim Illston}

is Head of the pensions team at Burges Salmon. He regularly advises trustees and employers of occupational pension schemes on all aspects of pensions law, including restructuring and dispute resolution. He has been a regular speaker on pensions subjects including taxation of pension schemes, estoppel and trustee powers. He is an Associate of the Pensions Management Institute and acts as an Independent Trustee of a number of pension schemes.

Abstract This paper reviews the development to date of the duty of good faith. It considers the way in which it has been applied differently in employment cases and pensions cases, and how the different authorities might be relevant in the context of a termination of a pension scheme. It also considers the possible response of trustees to a notice of termination, including a demand for increased contributions in the light of the Unisys New Zealand case.

Keywords: duty of good faith; trust and confidence; notice of termination; contributions rule; past underpayments

Tim Illston

Head of Pensions,

Burges Salmon,

Narrow Quay House,

Narrow Quay,

Bristol BS1 4AH, UK.

Tel: +44 (0)117939 2000;

Fax: +44 (0)117939 2000;

e-mail: tim.illston@

burges-salmon.com
The duty of good faith: how does it apply on the termination of a pension scheme?

There have been few reports of trustees successfully resisting an employer's decision to terminate its pension scheme. Where there has been resistance, this seems to have centred on specific provisions in the governing documentation of the scheme or contracts of employment. Given that the so-called 'duty of good faith' has become such an established principle of pensions law, it is a little surprising that trustees appear unable to make more of this in order to circumscribe the employer's power of termination. This paper considers how the duty of good faith might impact on the termination of a pension scheme, and it goes on to consider other ways in which trustees might respond to a notice of termination, including making a claim for increased employer contributions. Although some of the issues are relevant to other types of pension scheme, it has been written principally with final salary pension schemes in mind.

\section{The duty of good faith in the pensions context}

One of the difficulties faced by the legal adviser to any employer or trustees is the rather indeterminate scope of the duty of good faith in the pensions context. Its origins in the judgment of Browne-Wilkinson V-C in Imperial Tobacco $^{1}$ are well known. More recently, Brooke L J in the National Grid ${ }^{2}$ case encapsulated the duty in saying that it 'means that [the employer] must not, 
without reasonable and proper cause, conduct himself in a manner calculated or likely to destroy or seriously damage the relationship or confidence and trust between employer and employee. It is now well settled that the obligation of an employer applies as much to the exercise of his rights and powers under a pension scheme as it does to the other rights and powers of an employer.' However, in recent pensions cases the Courts have shown a readiness to use the shorthand 'duty of good faith' and to eschew the more informative longhand. ${ }^{3}$ For example, in the recently reported Hoover ${ }^{4}$ case, it was contended that the employer's power to withhold consent to an early retirement must be exercised in accordance with 'the general obligation of good faith'. In the Airways Pension Scheme ${ }^{5}$ case the High Court recognised that in the course of bargaining the employer had to comply with the 'duty of good faith'. Even their Lordships in the Privy Council in Air Jamaica ${ }^{6}$ referred to the company's obligation to exercise the power of amendment 'in good faith', without further definition.

\section{The duty as a fetter on the exercise of powers}

Not only do the Courts in the pensions cases apparently favour the shorthand expression of the duty, but they also tend to apply it as a fetter on the exercise of powers, rather than a free-standing substantive term. The characterisation of the duty as a doctrine of trust law relating to the proper exercise of powers was very clearly enunciated in National Grid. $^{7}$ Robert Walker J held that the duty of good faith prohibited the exercise of powers for collateral or improper purposes, citing the

Vice-Chancellor's statement in Imperial Tobacco that the obligation of good faith does require that the company "should exercise its rights (a) with a view to the efficient running of the scheme established by the fund and (b) not for the collateral purpose of forcing the members to give up their accrued rights in the existing fund subject to the scheme.'

This is not to say, however, that the implied fetter on powers does not apply in employment case law. In Clark $v$ Nomura, ${ }^{8}$ the employer's discretion whether to award a bonus was held to be fettered such that it could not be exercised irrationally or perversely, ie, in such a way that no reasonable employer would have done. The high threshold of perversity or irrationality matches the rigour of the longhand version of the duty of good faith as applied in other employment cases. The conduct of the employer must be likely to be so destructive or so unfairly or improperly exploitative as to be a repudiation of contract.

\section{The duty as a free-standing, substantive term}

Generally, the employment cases have tended to remain closer to the original longhand formulation than the pensions cases, and envisage the duty of good faith as a freestanding substantive implied term in the contract of employment rather than a fetter on the exercise of powers.

So, in Malik, ${ }^{9}$ where the employees successfully claimed that their employer (BCCI) had breached the duty by operating a dishonest and corrupt business that stigmatised them, the House of Lords took the view that breach of the duty would only occur if the conduct, looked at objectively, was 'likely to destroy or seriously damage the degree of trust and confidence an employee is reasonably entitled to have in his employer.' In Transco Plc v. 
O'Brien $^{10}$ where the employee successfully complained that by not being offered a revised contract he was the only permanent employee deprived of enhanced redundancy terms, the Court considered that he had been victimised and discriminated against in a manner which was calculated to destroy the relationship of trust and confidence between himself and his employer. These employment cases envisage conduct that is so destructive and fundamental that it amounts to a repudiation of the contract; and this must be more than a mere possibility, it must be a likelihood.

\section{Further development of the duty of good faith}

Although the use of the shorthand expression in the pensions context, and the concomitant uncertainty of meaning, makes the role of the legal adviser quite difficult, it leaves open the distinct possibility of further development of the doctrine in the pensions context.

The Courts have acknowledged that the scope and limits of the duty will be worked out on a case by case basis in years to come, ${ }^{11}$ and that in appropriate circumstances the duty might even have a positive as opposed to merely negative content. ${ }^{12}$ The working out of the duty might also bring much-needed clarity in the pensions context. To date, even the fundamental principles remain implicit rather than explicit; for example, that the duty is enforceable by trustees and is also a duty owed by the employer to trustees; that the principal employer in relation to a group scheme owes the duty to employees of other participating employers and also that it extends to beneficiaries who are neither employees nor former employees. ${ }^{13}$

How will the Courts develop and clarify the duty in the pensions context? How might it apply on a termination?
The answer to both of those questions may very well turn on whether the Courts develop the duty of good faith as a doctrine of trust law or return to its origins as an implied contractual term in the employment context. ${ }^{14}$ Or perhaps the Courts will acknowledge that case law has developed two distinct principles of law?

\section{Pointers suggesting how the duty of good faith might impact on the power of termination}

It is well settled that the duty of good faith does not prevent the employer from looking after its own financial interests, even where they conflict with those of members and pensioners. This has been a feature of the pensions cases on good faith. ${ }^{15}$ Most recently, in Hoover, the Court held that the employer could 'look to its own interests in reducing its potential exposure' in relation to the early retirement of the member.

The entitlement of the employer to take into account its own financial interests has been expressly contemplated in the context of its terminating a scheme. In Imperial Tobacco the Vice-Chancellor held that, although 'the duty of good faith requires the company to preserve its employees' rights and pension funds, not to destroy them ... if there are financial and other considerations which require the fund to be determined so be it.' Many employers and their advisers will have relied upon this comment to justify a position that termination may be made without breaching the duty of good faith.

The most explicit consideration of the duty of good faith demonstrating its potential application in this context is found in the determination by the Pensions Ombudsman in the National Bus case. ${ }^{16}$ In that case, the company and the trustee had entered into a deed of 
variation; the complainant alleged that the deed disadvantaged the membership. During the negotiations the company had proposed that it might immediately suspend its contributions and make no further contributions until the scheme's surplus had been exhausted. Given the company's ability to suspend contributions, the proposals made by the company for a series of guarantees and assurances were accepted by the trustees in exchange for the breaking of a linkage between increases to pensions in payment and increases in the national average earnings index, and the giving up by the trustee of a power over surplus on a winding-up.

The Ombudsman determined that the company was under an implied duty of good faith in the exercise of its powers. He asserted that the duty exists both in contract and under trust law, and he did not see any reason why the duty should not be owed by the employer to the scheme trustees as well as to the members. He determined that the company had threatened to exercise the power to suspend contributions in order to persuade the trustee to give up powers that it was required to exercise in the best interests of the members. $\mathrm{He}$ acknowledged the authority of Courage, ${ }^{17}$ permitting the employer to offer to increase benefits in exchange for trustees relinquishing a provision to prevent a surplus returning to the employer. However, he did not consider the proposal in National Bus was such an exchange. Instead, he characterised the conduct of the company as using a threat made for the purpose of inducing the trustee to agree to the change in benefits and to give up their right to augmentation on winding-up. The offering of advantages did not operate to offset the threatened use of its power to suspend contributions from constituting a breach of the duty of good faith. The
Ombudsman also considered that the use of the power to suspend contributions was an improper use of the power and that it was being exercised for a purpose beyond its scope or for an extraneous or ulterior purpose.

In these cases it seems quite likely that the Courts would accept that the duty of good faith applies to the power to terminate; and that a threat to terminate contributions used by the employer to secure changes in the scheme could be improper. ${ }^{18}$ However, the employer may counter this with the contention that it may take into account its own financial interests. In the current climate this is likely to be a convincing argument in many cases. The strains on funding a final salary pension scheme, exacerbated in recent years by improving mortality and the poor performance of equity markets, may very well provide sufficient grounds for an employer invoking its own financial interests. In addition, the employer may deploy other possible arguments.

Most radically, notwithstanding Imperial Tobacco, the employer might question whether the power of termination is subject to the duty of good faith at all. First, we have the comments of Lord Millett in Air Jamaica. Lord Millett characterised the company's power to discontinue the plan not as a power but as a liberty. One of the considerations was that a power would have been void for perpetuity, but could the characterisation of the power to discontinue as a liberty take the termination of contributions outside the scope of the duty of good faith? Secondly, if the duty is centred on the proper exercise of powers as a doctrine of trust law, how can the power to terminate be constrained by a duty that it be exercised 'with a view to the efficient running of the scheme'? How can it be used 'for a purpose other than 
the use for which the power was granted'? Equally, how can the exercise of the power to terminate be for a collateral purpose of forcing members to give up accrued rights?

If trustees are successfully to challenge a termination might they do better to draw on the second strand of case law, namely the employment cases that apply the duty as an implied contractual term, rather than the proper purpose doctrine of trust law?

\section{Do the employment cases help trustees?}

The Privy Council recently considered in Reda ${ }^{19}$ whether an express power to terminate a contract of employment without cause was subject to the duty of good faith. Certain employees were dismissed without notice and were thus deprived of stock options under a plan which was introduced shortly after their employment came to an end. The Privy Council accepted that Flag should not without reasonable and proper cause destroy the relationship of trust and confidence, and that this duty would have been breached if the employees had been victimised by being capriciously or arbitrarily singled out for dismissal in order to deprive them of their entitlement to participate in the stock option plan. However, it was held, following Johnson v. Unisys, ${ }^{20}$ that this duty must yield to the express provisions of the contract of employment (here the contract allowed them to be dismissed without notice) and that it cannot be used to circumscribe an express power of dismissal without cause. Lord Millett quoted Roskill L J in Nelson v. BBC: $:^{21}$

'... it is a basic principle of contract law that if a contract makes express provision ... in almost unrestricted language, it is impossible in the same breadth to imply to that contract the restriction of the kind that the Industrial Tribunal sought to do.'

In both Reda and Johnson, it appears that their Lordships were reluctant to extend the scope of the duty of good faith and have consistently applied the longhand version of the doctrine. More significant, though, is the recognition that an implied duty must yield to an express power. If this approach were carried across into the pensions context, it would emasculate the duty of good faith in many instances, but most obviously in relation to the power to terminate. $^{22}$

If these authorities mean that the power to terminate is not fettered, could trustees construct an argument that by terminating a pension scheme the employer is breaching the duty in its form as a free-standing substantive obligation? It is difficult to see a Court disregarding or distinguishing Johnson and the persuasive authority of Reda. Even if it were to do so, the threshold for a claim is high. An abrupt termination of a pension scheme, without any replacement arrangement, might in some circumstances breach the duty. These circumstances could be exacerbated, for example, if the employer is financially strong and has terminated the scheme in the full knowledge that the benefits for the members (certainly the active and deferred members) will not be secured in full. In addition, it seems quite possible that the Court would also take into account the expectations of members. ${ }^{23}$ So, for example, members may have legitimate expectations founded on their scheme booklet that benefits earned up to the date of termination would be provided in full, and might possibly continue to be linked to prospective final salary. In 
most circumstances, though, an employee would struggle to bring a successful claim.

In summary, if the duty of good faith is viewed as a fetter on powers, the employer might argue that:

- the proper purpose of a power to terminate self-evidently cannot be to support the continuation of the scheme;

— in any event, the employer can take into account its own financial interests;

- Reda suggests that the implied duty has to yield to an express power, at least in the context of terminating a relationship; and

- if the power is constrained by a proper purpose doctrine in the context of employment law, the constraint is merely that the power cannot be exercised perversely or irrationally.

Perhaps ironically, a threat to use the power is on current authority more likely to fall foul of the doctrine than the actual exercise of the power. (In some circumstances, though, the repeated giving of notice of termination followed by withdrawal of the notice, ${ }^{24}$ might be questionable if its exercise was not for the intended purpose but rather to extract concessions from trustees.) Finally, if the duty of good faith is applied in its freestanding substantive form the threshold will at the very least be challenging.

\section{The trustees' response to a notice of termination}

On receiving a notice of termination from an employer, the trustees should at least consider whether the notice is invalidated by a breach of the duty of good faith. They might ask the employer to provide written reassurance that it is not in breach of contract (including the implied duty) but ultimately they will need to reach their own opinion on legal advice. More generally, they have a duty to take reasonable steps to recover whatever assets they can establish are due to the scheme $e^{25}$ and, if necessary, take legal proceedings to do so unless the cost/benefit ratio is adverse. This duty may mean the trustees exploring a number of possible routes to maximise recovery, besides the 'duty of good faith' argument.

On receiving a notice of termination the trustees might quite reasonably question whether the notice is effective. Generally a notice will only take effect once all trustees have received it, unless they could be said to have delegated authority to any one of their number to accept notice on behalf of all of them. Where the governing documentation requires a period of notice to be given, the trustees must be satisfied both that the correct period of notice has been given and that the date of termination is clearly expressed in the notice. ${ }^{26}$ They need to bear in mind that a notice of this sort would take effect as construed through the eyes of a reasonable recipient taking into account the relevant contextual scene. ${ }^{27}$

Trustees will also need to consider whether to exercise any power they might have under the scheme constitution, or if relevant Section 38 of the Pensions Act 1995, to defer a winding-up. The deferral of winding-up would prolong the application of Section 58 of the Pensions Act 1995. Even though contributions might have been terminated under the rules of the pension scheme, contributions would remain payable on the basis of the minimum funding requirement for as long as winding-up is deferred. This is potentially a significant weapon in the hands of the trustees with the potential 
for committing the employer to many years of funding on the MFR basis (or its successor) as the scheme continues to be run on a closed basis.

In those cases where notice has to be given of a termination, the Unisys case ${ }^{28}$ has highlighted the possibility of trustees reassessing the rate of employer contributions payable during the notice period. In the case of Unisys, the company terminated employer contributions on one month's notice. The trustees responded by putting in a demand for funding sufficient to secure benefits by buying out benefits with an insurance company. The court held that it was legitimate for the trustees during that period of one month's notice to reassess employer contributions and make a further demand. In this case the contribution rule required the employer to pay 'the amount which the trustees (after considering the advice of an actuary and the Principal Employer) have decided is necessary to provide the benefits payable under the Plan.' Such 'trustee-friendly' wording is less common in the case of schemes established after the mid-1970s, but is by no means rare. In such cases, where the rule refers to 'securing benefits', 'providing the benefits', or similar, the trustees may have a good argument that the cost of buying out benefits with an insurance company on the subsequent winding-up of the Scheme should be met by the employer in its contributions during the notice period. Where different verbal formulae are used eg, 'maintaining the Scheme' or where references are incorporated to fixing contributions 'from time to time' or 'periodically' or there are other indicators of ongoing funding, the trustees will have lesser grounds to argue for buy-out costs. Nonetheless, the Ombudsman in the National Bus case provided an analysis that could help trustees even in the least favourable case.
In National Bus, the employer contribution rule stated:

'The Employers shall pay such periodical contributions to the Fund as the Trustee with the advice of the Actuary shall from time to time determine and agree with the Employers are, together with the Members' contributions ... and the assets for the time being of the Fund, appropriate to enable the Fund to provide benefits under Part IV of the Rules.'

The Ombudsman held that the contribution rule and the winding-up provisions had to be considered together (though Part IV did not include the winding-up provisions). The appropriate basis for the funding of the benefits depended on how those benefits were expected to be provided. Where the winding-up rule was expected to come into operation, the funding should have been based on the cost of securing those benefits on the winding-up. As is generally the case, the choice of how to provide benefits on a winding-up was given to the trustee. The winding-up rule provided that annuities should be purchased to secure the benefits, though the trustee also had a discretion to secure benefits by transfers or paying benefits from the scheme as a closed fund. The Ombudsman considered that these alternatives would only be selected if the trustee considered significantly higher levels of benefits could be achieved as against the greater security offered by annuities.

The Ombudsman also determined that the requirement that the company agree to the rate of contributions did not allow it to withhold consent in order to force the trustee to adopt a particular method for securing benefits on winding-up: 'The company could not insist that the contribution rate should be calculated on the basis that the scheme was ongoing ... when it was not expected to be so. 
Nor, once winding-up was expected, could it insist upon a contribution rate in the interim that would be likely to prevent the trustee from purchasing annuities to match the promised benefits ... or only allow benefits to be secured $\ldots$ and the price of an abatement of benefits.' The company had to agree to an appropriate contribution rate.

Furthermore, the promise to pay contributions on an appropriate basis was in the Ombudsman's determination not intended to be undermined by the Company's right to suspend contributions.

In cases where notice has to be given of termination, the same principle might apply: the payment of contributions on the appropriate basis is not to be undermined by the termination. Thus, even in the case of a 'trustee-unfriendly' contribution rule, where contributions are determined by the employer or at least require its agreement, the trustees can require the employer to perform its duty properly in paying contributions during the notice period on a basis that satisfies the terms of the rule. If it fails to do so, then it might arguably be in breach of the duty of good faith. It is doubtful that the employer could negate a substantive obligation to meet the cost of securing benefits during the notice period on grounds that it is acting in its own financial interests. A counter-argument is that Section 75 of the Pensions Act 1995 was introduced specifically to provide the appropriate basis for payment of a shortfall on winding-up, but express provisions of a scheme to the contrary would probably prevail.

\section{Past underpayments}

Unisys has focused greater attention on the possibility of increasing the contributions payable during a notice period. However, trustees should also be alert to the possibility of bringing a claim for underpayment of contributions historically. If the employer has paid contributions on an ongoing basis in the knowledge that the scheme is likely to be wound up, the trustees could argue that the employer has breached the duty of good faith. It may be said to have failed to exercise its power to assess contributions properly in that it did not do so with a view to the efficient running of the scheme or did so irrationally or perversely. Alternatively, this might be the type of conduct that would breach the freestanding substantive duty. $^{29}$

It may even be that employees or former employees might themselves have a valid claim for past underpayments. It is clear from Malik that damages can be claimed by former employees in respect of the general conduct of the employer prior to termination of employment. There may be circumstances where an employer has deliberately assessed or agreed contributions to its pension scheme at a level it knows to be insufficient to provide the benefits promised. There seems to be evidence in the case law of perhaps a greater readiness to impose a duty on employers to pay contributions than to procure delivery of benefits. ${ }^{30}$

\section{Expenses}

Even though contributions may have been terminated by the employer, the trustees will wish to consider whether any liability remains for the employer to continue paying expenses. Quite frequently, a provision for termination of contributions will omit reference to expenses. The debt on the employer regulations include allowance for expenses by reference to GN27, ${ }^{31}$ but in some circumstances the employer's 
liability under the Scheme rule may be greater. There may even be the possibility of double recovery.

Do the trustees owe a reciprocal duty to the employer? In practice, a claim by trustees for further or increased contributions will result in a process of bargaining. How hard should the trustees bargain? Should they take the interests of the employer into account? ${ }^{32}$

It is well recognised that trustees have a duty to the employer as a beneficiary where it has an interest in surplus under the winding-up rule. It also well established following $E d g e^{33}$ that trustees should not take an action which might imperil the existence of the employer. Shadwick L J found it 'an astonishing proposition' that trustees should have put forward proposals that they did not think were fair to the employers. In Courage, Millett J observed that the trustees' only sensible and proper course was to make such recommendations as they felt to be fair to everyone involved in the fund. However, both cases related to the use of surplus and took into account the need to maintain the goodwill of the employers for the future. In cases where the accrual of future service benefits is no longer a relevant consideration, and there is no surplus, any concept of fairness to the employer is likely to take second place to the duty of the trustees to maximise recovery in order to pay as much of the benefit entitlements due as they can.

A further development in the duty of good faith could, however, change this position. In employment law, the duty of good faith is established as a mutual duty, ${ }^{34}$ and in South West Trains ${ }^{35}$ it was held in relation to the train drivers on whose behalf the case was brought against SWT as employer, that it must be implicit in the contract [of employment] that the driver would not seek from the Trustees the payment of pension on a more generous basis than that agreed with SWT.' If the principle of mutuality is developed, any express recognition that the duty of good faith is owed by the employer to the trustees might conceivably also carry with it the corollary that the trustees owe the employer the same duty. In the absence of any such duty owed to the employer, the trustees might be seen as having the upper hand against an employer whose powers are fettered by the duty of good faith.

\section{Conclusion}

There is no doubt that the duty of good faith in the pensions context is well established. However, its impact in the context of the termination of the pension scheme remains uncertain. As a facet of the doctrine that powers must be used for their proper purpose, it is difficult to see how in normal circumstances the actual exercise of the power of termination (as opposed to a threat to exercise) can be challenged as having been misused for a collateral purpose or exercised perversely or irrationally. In any event, the Courts might conclude that the implied duty of good faith should yield to an express power to terminate. The trustees or employees are also faced with a challenging threshold in order to establish a breach of the duty expressed as a freestanding substantive duty. Nonetheless, there is undoubtedly scope for the duty to be further developed or clarified. Is it intentional that two separate strands of case law appear to have developed? What aspects of the duty as it applies between an employer and employee cross over into the relationship between employer and trustees? Will the apparently more rigorous approach in the employment cases cross over into pensions law? Is there a reciprocal duty owed by trustees 
to the employer? The termination of the scheme is fertile subject matter for a definitive judgment on these issues, bringing together as it does aspects of the contract of employment and the law of trusts.

Trustees may have greater cause for optimism in examining whether contributions are payable during any period of notice. It is quite common for contribution rules to refer to contributions to secure or provide benefits. Following the lead of the Ombudsman in National Bus and the New Zealand High Court in Unisys, trustees should make what they can of a favourable contributions rule. Even in the case of a rule under which the employer has a role in assessing contributions, the trustees can argue that the employer has to carry out its duty in compliance with the duty of good faith. The final thought is that, despite the strength of the possible

counter-arguments, the running of a 'breach of duty of good faith' argument against an employer must be a matter that any trustees faced with a notice of termination if the facts give reasonable support to such a claim. Given the uncertainty of the limits of the duty, and the scope for its development, trustees might find this approach brings unexpected returns from their beneficiaries.

\section{References}

1 Imperial Group Pension Trust v. Imperial Tobacco Ltd [1990] PLR 263.

2 National Grid Co Plc v. Laws [1999] PLR 37.

3 In Hillsdown v. Pensions Ombudsman [1996] PLR 427, Knox J expressly recognised that 'the obligation of good faith' was a convenient form of shorthand.

4 Hoover Ltd v. Robert Hetherington and Hoover [2002] PLR 297.

5 Stevens \& Others v. Bell \& Others [2001] PLR 99.

6 Air Jamaica v. Charlton [1999] PLR 247.

7 National Grid Co Plc v. Laws, Mayes \& Others [1997]

PLR 157.

8 [2000] IRLR 766.
9 Malik \& Mahmud v. BCCI [1998] AC 20. See also Reda v. Flag LTL 12/7/2002, where the Privy Council accepted the inclusion of an implied term in the contract of employment that the employer would not 'without reasonable and proper cause destroy the relationship of trust and confidence between employer and employee.'

10 [2002] IRLR 441.

11 Robert Walker J acknowledged this expressly in National Grid Co Plc v. Laws, Mayes \& Others [1997] PLR 157.

12 Hart $\mathrm{J}$ held in University of Nottingham v. Eyett [1999] PLR 25 that the duty of good faith imposed a negative duty and to impose a positive duty would be an extension of existing law. In fact, in South West Trains v. Wightman [1998] PLR 113 Neuberger J considered that an employer would be obliged to stop employees from trying to claim both existing pension rights and pay increases out of its duty and to other employees.

13 It is certainly implicit in Imperial Tobacco that the duty is enforceable by the trustees and in Hillsdown and National Grid that it is a duty owed to trustees. It is clear from Spring v. Guardian Assurance plc [1995] 2AC 296 that the duty extends to former employees.

14 Its development arguably stems from Woods v. WM Car Services (Peterborough) Ltd [1982] ICR 693 when the Court of Appeal accepted the implied term so as to allow an employee to bring a claim for unfair dismissal.

15 For example, in Stevens $v$. Bell the employer was held to have had a legitimate interest, if the circumstances were right, in securing the return of part of the surplus in the course of bargaining with the trustees.

16 National Bus Company [1997] PLR1.

17 Re Courage Group's Pension Schemes, Ryan v. Imperial Brewing [1987] 1 All ER 528.

18 See also Hillsdown v. Pensions Ombudsman [1996] PLR 427 where Knox J commented that threatening to use its power to admit new employers in order to run off a surplus would be a breach of the duty of good faith.

19 Reda v. Flag Ltd LTL 12/72002

20 In Johnson v. Unisys [2001] 2 WLR 1076 the House of Lords held that the implied duty cannot be used to extend the employment relationship beyond its agreed duration.

21 Nelson v. British Broadcasting Corporation [1977] IRLR 148.

22 For example, it is difficult to reconcile this approach with the implied fetter placed by the Courts on the express power to adhere new employees to a scheme (Hillsdown), to withhold consent to pension increases (Imperial Tobacco) or to decide on the use of surplus (National Grid).

23 British Coal Corporation v. British Coal Staff Superannuation Scheme Trustees [1993] PLR 303.

24 As occurred in McClelland $v$. Unisys New Zealand Ltd [2002] PLR 87.

25 Re Brogden (1888) 38 ChD 546. 
26 Grammar School of John Lyons v. Secchi [1999] EGCS 118.

27 Mannai Investments Co Ltd v. Eagle Star Life Assurance Co Ltd [1997] AC 749.

28 McClelland v. Unisys New Zealand Ltd [2002] PLR 87.

29 In Scally v. Southern Health and Social Services Board [1991] PLR 195 the employer was held to be under a duty to inform employees of their pension rights. If this aspect of the duty of good faith was translated from the employer/employee relationship to the employer/trustee relationship, could an employer be under a duty to tell the trustees as soon as it had formed an intention to wind up the scheme in order to enable the trustees to reassess the rate of employer contributions?

30 For example, in Jeffs $v$. Denham Brindley \& Linn Pensions Ombudsman determination KD0165 [2001], the Ombudsman held that failure to have paid contributions would have amounted to a breach of the employers duty of good faith. In Frankling $v$. BPS Public Sector [1999] OPLR 295, the Employment Appeal Tribunal considered that the employer was under a contractual obligation to make payments to the scheme to enable the eligible employee to receive payment of benefits even though there was no contractual obligation to procure these specific benefits. In Stannard v. Fisons [1990] PLR 201, Staughton L J thought it might be that a reduction of employer contributions could in some circumstances be a breach of the contracts of employment.

31 Occupational Pension Schemes (Deficiency on Winding-up etc) Regulations 1996 and Guidance Note 27 issued by the Institute of Actuaries and Faculty of Actuaries.

32 In the case of Bradstock Group Pension Scheme Trustees Ltd Bradstock Group plc and others [2002] PLR 327, Charles Aldous QC held that debt on the employer arising under Section 75 of the Pensions Act 1995 could properly be compromised by trustees. The compromise for considerably less than the full amount of the MFR deficit was not occasioned by any consideration of the employer's own interests. Rather the terms of the compromise appear to have been reached on the basis that no better terms could be secured by forcing the company into liquidation.

33 Edge v. Pensions Ombudsman [1999] PLR 215.

34 South West Trains v. Wightman [1998] PLR 113.

35 See for example, Faccenda Chicken Ltd v. Fowler [1986] 3 WLR 288. Malik also emphasises the reciprocal nature of the duty. 